\title{
Climate Change and Health Protection in European Union
}

\author{
By Radu Ioan Mogos ${ }^{1}$, Negescu-Oancea Mihaela Diana ${ }^{1}$, Sorin Burlacu ${ }^{1}$, \\ Victor Adrian Troaca ${ }^{1}$
}

\begin{abstract}
Climate change (CC) represents a real fact with consequences that start to be seen more and more often and that is why it cannot be ignored anymore. It affects many domains of the human activities and also the health of the people. Climate-specific actions are needed to be taken in order to protect the people and to save the environment. For each affected domain, new regulations and actions regarding climate change prevention must be designed, promoted and implemented. Besides phenomena like heat waves, storms, increased temperature, forest fires, floods, etc. which represent direct results of the CC, also indirect results like human health may be encountered. Human health is affected by elements that are having a big impact over the environment of the people and over the resources that they need (resources like water, food, air, natural resources, etc.). CC has also implications on people migration, the fight over the natural resources, political and economic environments. This paper offers an overview of the most important factors that are affecting the health of the people from the CC point of view and which are the main challenges that most affected countries from EU are dealing with.
\end{abstract}

Keywords: climate change, buman bealth, environment, data mining analysis

\section{Introduction}

During the last 20 years, according to the analysis financed and made by European Union (EU) and World Health Organization (WHO), it is shown that our planet is getting warmer generally due to $\mathrm{CO} 2$ emissions level. For this reason, the climate is changing and the extreme weather events occur more and more often. Events like rising average temperatures, floods, landslides, droughts, rising sea levels, decreasing the glacier in extent and volume, ocean currents are affecting the lives of millions of people every day in different ways. In Europe, we can see already an increased number of heat waves with an increasing duration and frequency, an increase in the rainfall intensity and quantity. Some other phenomena can be observed in the north and central part of the Europe where intense flooding along the watercourses and in the coastal area occur because of the increased precipitation. According to EU Regional policy (EU-RP 2009), since year 2009, $62 \%$ of the questioned people of EU had considered that $\mathrm{CC}$ represents the most significant threat that the world confronts with today from which a series of extreme events and natural disasters occur. These extreme events are linked to the climate change and in a large extend they are affecting the lives of millions of people and, in an implicit way, their health (Pricop et al., 2016). According to Talukder et al. (2021), the food and 
nutritional security of two billion people around the world depend largely on smallholder farmers (Radulescu et al., 2020). Papers like (Ricciardi et al. 2018) and (Khalil et al. 2017) are also debating this problem.

The relation between these extreme events / natural disasters and human health is a very strong one (Carra, C. et al., 2018). World Health Organization has identified that the health may be affected by the seasonality and geographic range of some specific infectious diseases which reach the highest numbers of infections when the temperatures are high (egg. of diseases: food-borne infections like salmonellosis, vector-borne infections like dengue fever and malaria, people with allergies, asthma cases). Also, having high temperatures and low temperatures in short and very short period of time will lead to thermal extremes and resultant health impacts. Many of these events are also destroying the environment in which many people are living (Carra et al., 2016, 2017). For this reason, the daily lives of many of them are changed for a certain period of time from a social and economic point of view (Burlacu et al., 2021). In these situations, food-production capacity related problems may appear. In some cases, they must move from their initial areas, movement that will lead to a big mental and physical discomfort (Faggianelli et al., 2018). This kind of effect over the human health may be seen only after several years (Sarbu et al., 2021).

Across the Europe, several projects were developed, projects that aims different aspects of CC. Some ongoing projects are the following (CA-EE 2021): B4EST(Adaptive BREEDING for productive, sustainable and resilient FORESTs under climate change), CAScading (Climate risks: towards ADaptive and resilient European Societies), COACCH (CO-designing the Assessment of Climate CHange costs), Cities Nature Innovation, SOCLIMPACT (DownScaling CLImate imPACTs and decarbonisation pathways in EU islands, and enhancing socioeconomic and non-market evaluation of Climate Change for Europe, for 2050 and Beyond), SolACE (Solutions for improving Agroecosystem and Crop Efficiency for water and nutrient use), URBAN GreenUP.

In order to understand and reduce the health threats caused by the CC, the European Commission and the European Environment Agency, along with other important players in the field, have launched the European Climate and Health Observatory. Its goal is to identify and highlight connections between CC and health and also to offer sustainable solutions for medium and long term (CA-OBS 2021). Concerning the regional areas, creating sustainable local green jobs and development it may represent a solution on a medium and long term (Bran et al. 2020).

\section{Impact Factors Over the EU People Health}

The impact of CC on human health is complex, with many implications, both at the individual and societal level. Factors resulting from CC may have a direct impact (such as temperature-related illness and death, and extreme events) or indirectly (medical services that can no longer function at maximum capacity). Also, an important aspect of CC is the natural disasters that occur due to these factors. But all of them are contributing to the deterioration of human health. Figure 1 shows Europe and the countries that were affected by natural disasters in the period 2000-2020. 


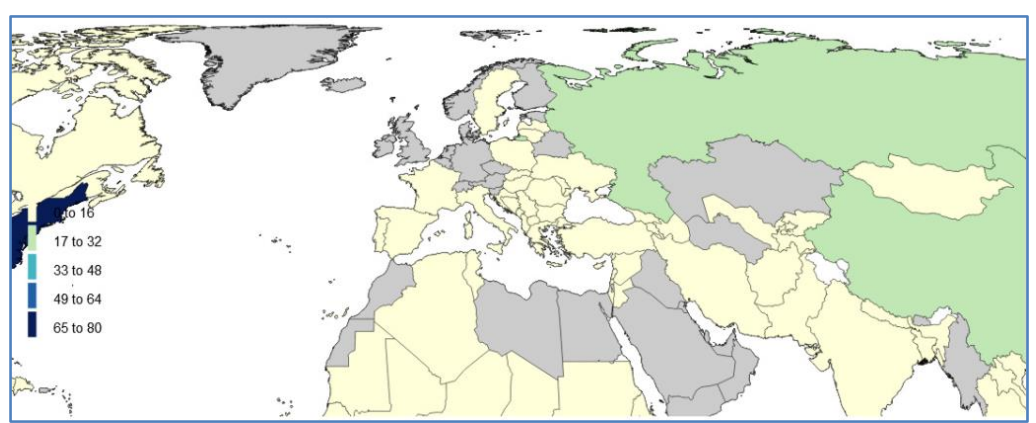

Figure 1: Global occurrence from Climatological Disasters between 2000 and 2020.

Source: EM-DAT, CRED/UCLouvain, Brussels, Blegium - www.emdat.be (D.Guba-Sapir)

According to Menne (2021) there are a lot of ways in which the public health is and will be affected. From this point of view, for EU are indicated the following:

- the heatwaves are considered to become a very present problem and until the year 2100 there is expected to be the reason of up to 90000 excess deaths per year in the EU, and to have also an economic cost impact of over 150 billion EURO if no further specific actions are taken. One reason of these high temperatures especially in the industrial and city areas is the air quality and pollution which is most affected by the $\mathrm{CO} 2$ gas emissions. Breathing, cardiovascular, mental focusing, effort resistance problems are just some examples of the negative impact over the human health of the air pollution. Also, having higher temperatures and summers with high humidity in new areas, disease-carrying insects (like dengue, malaria, Lyme disease) may thrive. Research papers like (Fisher et al. 2010) and (Lhotka et al. 2018) are debating this problem.

- wildfires - The probability of forest fires is predisposed to a sharp increase in the near future with the increase of global warming. Usually, the areas in southern Europe are the most prone but, given the latest events, even in northern Europe may occur (egg. UK, Sweden). The health problems related to these events may consist in respiratory problems. Papers like (Dupuy et al. 2020) and (Ruffault et al. 2020) debate also this problem.

- water resources - another effect of global warming is that there is more rainfall in northern Europe which will lead to an increased number of water sources in the north and in a decreased one in the south. Southern Europe will be the most affected in terms of water sources and ground water level. Papers like (Beniston and Stoffel, 2014) and (Özerol et al. 2020) debate also this problem.

- alpine habitat loss - this habitat occurs at the top of high mountains in Europe and about $98 \%$ of its area is in the Pyrenees, Alps and Scandes. This area contains a very rich biodiversity and provides key ecosystem services. Because of the very strong links between ecological-climatic bands in mountains, CC could have major effects over the alpine ecosystems (Gentili et al. 2015, Barredo et al. 2020).

- energy supply - within Europe, energy sources are varied. In the northern area where water sources and rainfall are more, the energy produced in hydroelectric power units is used to a greater extent. Depending on the area and the country, the raw materials used to obtain energy is different and in many cases there a mix of energy sources (Newbery 2016, Gallego-Schmid et al. 2020). 
- windstorms - Wind storms are also becoming more and more present in Europe. Due to the large differences in temperature and air pressure, they end up having a very high forward speed. For this reason, they are one of the extreme events that cause the greatest damage when they occur. According to Feyen \& Ciscar (2020), in Europe it is estimated that it would cause annual damage of about 5 billion Euros.

- droughts - a situation that is making its presence felt more and more in some parts of Europe, while in others it is attenuating. The most affected areas in Europe are those in the south and west. Research papers like (Koutroulis et al. 2019) and (Peptenatu et al. 2013) debate also this problem.

- the coastal and river floods are another event that may affect in a very negative way the health of the people, damaging also large inhabited areas. In order to rebuild those areas, a lot of time, effort and money are needed. In inhabited places affected by the flood, the diseases may spread very quick based on the lake of drinking water and food and due to the large time until a possible rescue intervention. For example, in the year 2014 a flood took place and has affected the several countries, among them being Croatia, Bosnia and Serbia. This flood has caused around 60 deaths and has affected more than 2.5 million people. According to Davies (2019), between October and November 2019, in Europe it was a totally amount of 680 flood notifications (54 of them formal notifications, 39 informal notifications and 587 flash notifications). Some direct consequences of the floods with negative impact over the human health and also over the environment are contamination of the agricultural land and of the drinking water. During the flooding event, some unsecure kept chemical solutions may flow into lakes, rivers, seas and oceans and to enter into our food chain.

Several studies and researches have tried to identify the economic and social impact of the CC and the extreme events and natural disasters that are related with. The JRC PESETA IV (PESETA 2021) study has analyzed this impact, making also a simulation for year 2100 how the above mentioned factors will affect the EU citizens from two points of view, namely if no action is taken and if climate mitigation is done. There are also mentioned several adaptation mechanisms to improve all the sectors. The conclusions of this study are presented in Table 1 (Feyen et al. 2020). In figures 2, 3 and 4 are mentioned the variation values for the two scenarios and measures for people protection. The premises of these scenarios are as follows:

- scenario no. 1 - no action is taken: impacts under 3,0 $\mathrm{C}$ global warming scenario and assumes the population and economy do not change from present.

- scenario no. 2 - climate mitigation is done: impacts under $1,5^{\circ} \mathrm{C}$ global warming scenario and assumes the population and economy do not change from present.

Table 1. CC related extreme events and impact over the EU citizens scenarios for year 2100.

\begin{tabular}{|l|l|l|c|c|l|}
\hline No & Sector & Metric & $\begin{array}{c}\text { No action } \\
\text { scenario }\end{array}$ & $\begin{array}{c}\text { Climate } \\
\text { mitigation } \\
\text { scenario }\end{array}$ & $\begin{array}{l}\text { Adaptation } \\
\text { mechanisms for } \\
\text { protection }\end{array}$ \\
\hline 1 & $\begin{array}{l}\text { Heat and } \\
\text { cold } \\
\text { mortality }\end{array}$ & $\begin{array}{l}\text { Number of } \\
\text { people }\end{array}$ & $\begin{array}{c}90000 \\
\text { additional deaths } \\
\text { every year from } \\
\text { heatwaves in } 2100\end{array}$ & $\begin{array}{c}30000 \\
\text { additional deaths } \\
\text { every year from } \\
\text { heatwaves in 2100 }\end{array}$ & $\begin{array}{l}\text { 1. Improves isolation } \\
\text { 2. Green roofs } \\
\text { 3. Urban vegetation } \\
\text { 4. Early warnings }\end{array}$ \\
\hline
\end{tabular}




\begin{tabular}{|c|c|c|c|c|c|}
\hline No & Sector & Metric & $\begin{array}{l}\text { No action } \\
\text { scenario }\end{array}$ & $\begin{array}{c}\text { Climate } \\
\text { mitigation } \\
\text { scenario } \\
\end{array}$ & $\begin{array}{l}\text { Adaptation } \\
\text { mechanisms for } \\
\text { protection }\end{array}$ \\
\hline 2 & Wildfires & $\begin{array}{l}\text { Number of } \\
\text { people }\end{array}$ & $\begin{array}{c}15 \text { million } \\
\text { additional people } \\
\text { exposed to high } \\
\text { wildfire danger } \\
\text { every year }\end{array}$ & $\begin{array}{c}5 \text { million } \\
\text { additional people } \\
\text { exposed to high } \\
\text { wildfire danger } \\
\text { every year }\end{array}$ & $\begin{array}{l}\text { 1. Public awareness } \\
\text { campaigns } \\
\text { 2. Landscape and } \\
\text { vegetation management }\end{array}$ \\
\hline 3 & $\begin{array}{l}\text { Water } \\
\text { resources }\end{array}$ & $\begin{array}{l}\text { Number of } \\
\text { people }\end{array}$ & \begin{tabular}{|c|}
13 million \\
additional people \\
living in areas with \\
very few water \\
\end{tabular} & $\begin{array}{c}7 \text { million } \\
\text { additional people } \\
\text { living in areas with } \\
\text { very few water }\end{array}$ & $\begin{array}{l}\text { 1. Water prices } \\
\text { 2. Improved cooling } \\
\text { 3. Reduce water } \\
\text { dependency }\end{array}$ \\
\hline 4 & $\begin{array}{l}\text { Alpine } \\
\text { habitat loss }\end{array}$ & $\begin{array}{l}\text { Percentages } \\
(\%)\end{array}$ & $\begin{array}{l}84 \% \\
\text { alpine domain } \\
\text { reduction }\end{array}$ & $\begin{array}{l}48 \% \\
\text { alpine domain } \\
\text { reduction }\end{array}$ & $\begin{array}{l}\text { 1. Increase conservation } \\
\text { areas } \\
\text { 2. Create ecological } \\
\text { corridors } \\
\text { 3. Ecological restoration } \\
\text { 4. Assisted migration }\end{array}$ \\
\hline 5 & $\begin{array}{l}\text { Energy } \\
\text { supply }\end{array}$ & $\begin{array}{l}\text { Percentages } \\
(\%)\end{array}$ & \begin{tabular}{|c|}
$3 \%$ \\
increase in \\
hydropower \\
$<1 \%$ \\
decline in nuclear \\
and other thermal \\
\end{tabular} & \begin{tabular}{|c|}
$1 \%$ \\
increase in \\
hydropower \\
$<1 \%$ \\
decline in nuclear \\
and other thermal \\
\end{tabular} & $\begin{array}{l}\text { 1. Less water intensive } \\
\text { cooling }\end{array}$ \\
\hline 6 & Windstorms & Euro & $\begin{array}{c}6.8 \text { billion } \\
\text { additional annual } \\
\text { losses in } 2100\end{array}$ & \begin{tabular}{|c|}
6.8 billion \\
additional losses in \\
2100
\end{tabular} & $\begin{array}{l}\text { 1. Structural measures } \\
\text { 2. Emergency } \\
\text { communications } \\
\text { 3. Strom readlness } \\
\text { 4. Improve forecasts }\end{array}$ \\
\hline 7 & Droughts & Euro & $\begin{array}{c}16 \text { billion } \\
\text { additional annual } \\
\text { losses in } 2100\end{array}$ & $\begin{array}{c}36 \text { billion } \\
\text { additional annual } \\
\text { losses in } 2100\end{array}$ & $\begin{array}{l}\text { 1. Early warnings } \\
\text { 2. Lighter vessels } \\
\text { 3. Drought resistance } \\
\text { 4. Cooling techniques }\end{array}$ \\
\hline 8 & $\begin{array}{l}\text { Coastal } \\
\text { floods }\end{array}$ & Euro & $\begin{array}{c}238 \text { billion } \\
\text { additional annual } \\
\text { damages in } 2100\end{array}$ & $\begin{array}{c}110 \text { billion } \\
\text { additional annual } \\
\text { damages in } 2100\end{array}$ & $\begin{array}{l}\text { 1. } 12 \text { billion additional } \\
\text { annual for raising dykes }\end{array}$ \\
\hline 9 & River floods & Euro & $\begin{array}{c}40 \text { billion } \\
\text { additional annual } \\
\text { damages in } 2100\end{array}$ & $\begin{array}{c}16 \text { billion } \\
\text { additional annual } \\
\text { damages in } 2100 \\
\end{array}$ & $\begin{array}{l}\text { 1. } 1 \text { billion additional } \\
\text { annual to store excess } \\
\text { flood water }\end{array}$ \\
\hline 10 & Welfare & Euro & $\begin{array}{l}175 \text { billion } \\
\text { additional annual } \\
\text { welfare loss }\end{array}$ & $\begin{array}{c}42 \text { billion } \\
\text { additional annual } \\
\text { welfare loss }\end{array}$ & $\begin{array}{l}\text { 1. Adaptation to crop yield } \\
\text { changes, droughts, energy } \\
\text { production, ad river and } \\
\text { coastal flooding }\end{array}$ \\
\hline
\end{tabular}

Source: https:// ec.europa.eu/jrc/en/peseta-iv, 2021 


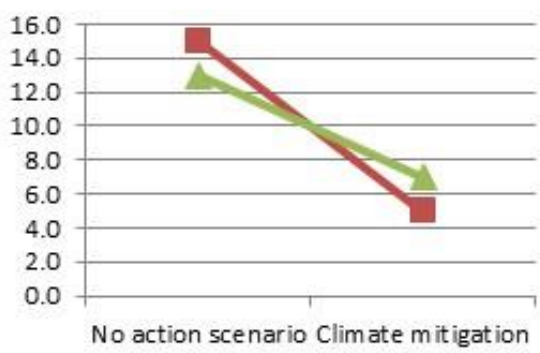

Wildfires (number of people - million)

Water resources (number of people million)

Figure 2: Wildfires and Water resources scenarios.

Source: https:// ec.europa.eu/jrc/en/peseta-iv, 2021

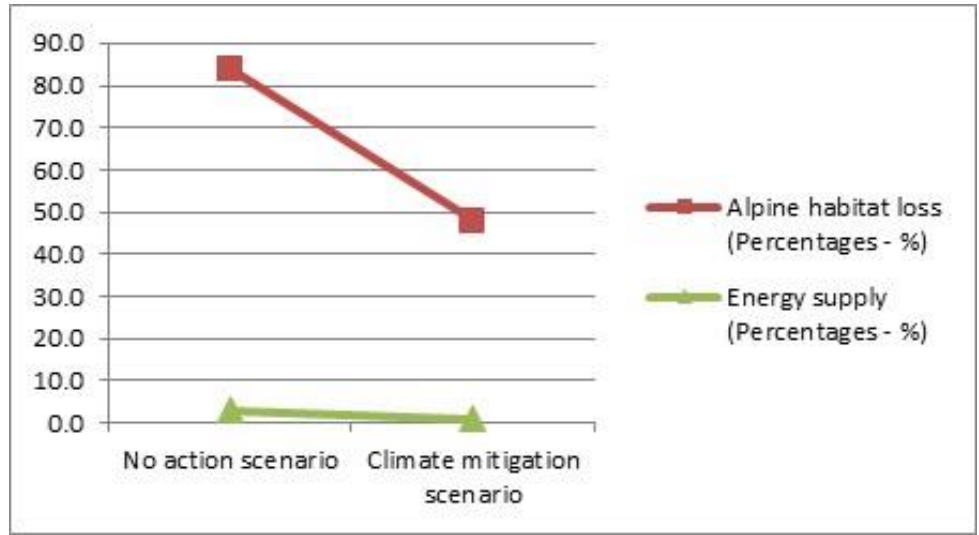

Figure 3: Alpine habit loss and Energy supply.

Source: bttps:// ec.europa.eu/jrc/ en/peseta-iv, 2021

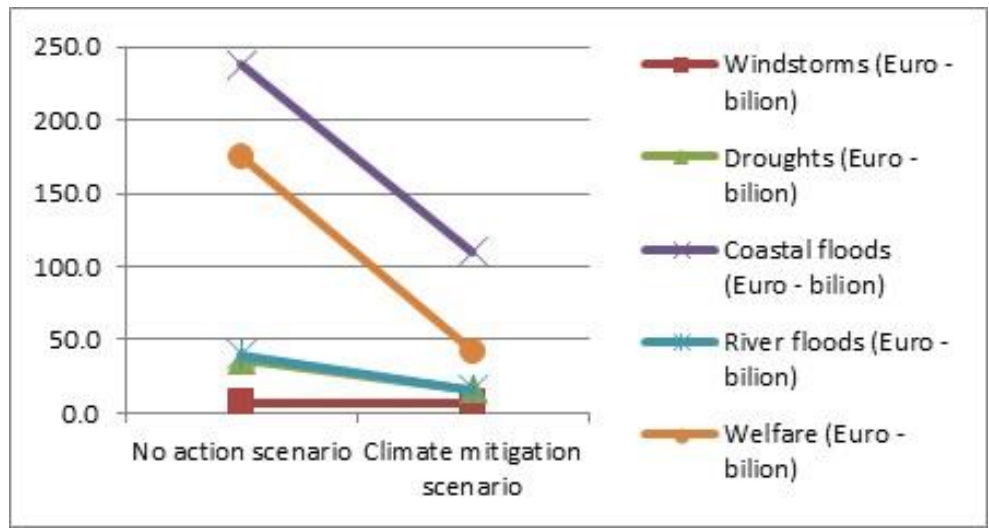

Figure 4: Windstorms, droughts, coastal / river floods and welfare.

Source: https:// ec.europa.eu/jrc/ en/peseta-iv, 2021 
According to WHO (WHO-CL 2021), usually, CC conditions can have three kinds of health impacts over the people:

- those that are relatively direct, in general caused by weather with extreme temperatures.

- different processes of environmental change and ecological disruption with health consequences that occur in response to CC.

- the diverse health consequences like - infectious diseases, traumatic mental or physical problems, nutritional issues, and other - that occur for hopeless and removed populations in the wake of climate-induced economic dislocation and environmental decline.

The effects of each factor resulting from CC that can influence people's health is also amplified by the location, the population density in the characteristics of the region, the degree of development, the medical services available, their quality and the speed with which they are achieved. For example, in the case of a population with a very high density in a certain region, it will lead to the spread in a very short time of some categories of diseases that are easily transmitted from one person to another. Policies and strategies for the development and maintenance of the environment and the services offered to people play a decisive role in ensuring and maintaining their health. From this point of view, an important aspect that represents a continuous challenge is the financial one and implicitly the amounts of money necessary to prevent the occurrence of extreme phenomena and natural disasters that occur as a result, to keep the air as clean as possible and unpolluted and to restore human health as a result of these effects.

\section{Methodology and Experiment Data}

One of the main challenges in preventing and combating the effects of CC on human health is to provide the financial resources needed for it. In this section, an analysis is made of 21 countries within the EU and which aims at a clustering process on them in terms of Gross Domestic Product data. It is well known that the air quality and the pollution have a great impact over the people's health.

The research questions for which the analysis tries to offer an answer are how many types of countries can be identify between European countries and which are the most representative one for each type?

The analyzed data represent a percentage of Gross Domestic Product (GDP) spent by the countries on welfare cost of premature deaths in general due to low air quality and pollution. The data source is STAT-OECD (2021) and the information taken into account is for the years 1990, 1995 and 2000 and for the period $2005-2019$.

The WEKA platform (https://www.cs.waikato.ac.nz/ml/weka/) and the DM - CRISP methodology (https://www.datascience-pm.com/crisp-dm-2/) are used to achieve this clustering experiment. DM-CRISP methodology consists in several steps, namely: requirements understanding, data understanding, data preparation, data modeling, evaluation and deployment. For deployment two cluster algorithms were used, as follows: EM algorithm (Expectation Maximization - algorithm that assigns a probability distribution to each instance which indicates the probability of it belonging to each of the clusters/type) was used to analyze the data in order to identify the optimal number of types and then the Simple K-Means algorithm to determine the main characteristic for each type based on the analyzed period of time. 


\section{Data Analysis Experiment and Results}

The dataset comprises 20 relevant attributes and 21 instances. An instance offers information about a country regarding the percentage of the GDP spent on welfare cost of premature deaths due to low air quality and pollution. In Figure 5 there are represented the attributes from the dataset and the values for the country attribute.

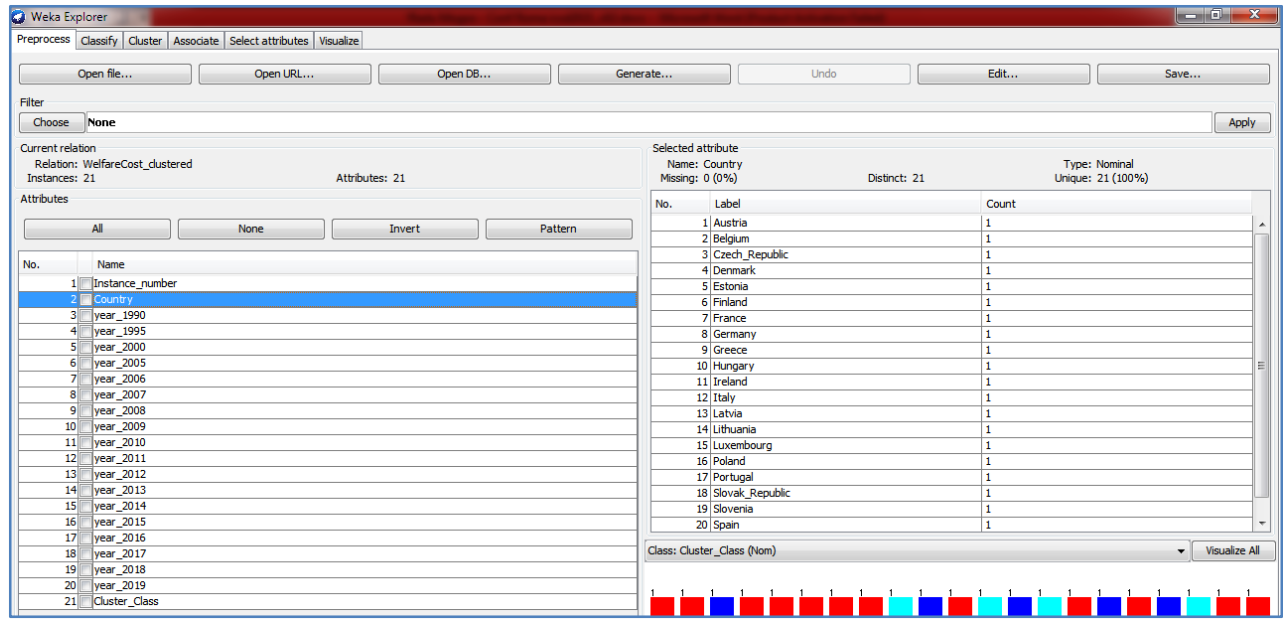

Figure 5: Dataset - attributes and countries

The number of country types according to the analyzed values and to the EM algorithm is 3 and based on the Simple K-Means algorithm the results are shown in Figures 6 and 7. The distribution of the instances (countries) in the clusters is as follows:

- Cluster 0: has 5 instances (24\%) and contains the following countries: Czech Republic, Hungary, Latvia, Poland, and Slovak Republic. The average percentage of GDP spent on welfare cost of premature deaths due to $\mathrm{CO} 2$ gas emissions, low air quality and pollution for year 2019 is about $6.8 \%$. Over the years, this average decreases from $11.95 \%$ in 1990 to $6.8038 \%$ in 2019 . The most representative country for this group is Czech Republic. For this group, the difference between 1990 and 2019 is quite double.

- Cluster 1 with 12 instances (57\%) contains: Austria, Belgium, Denmark, Estonia, Finland, France, Germany, Ireland, Luxembourg, Portugal, Spain, and Sweden. The value decreases over the years, starting from 5,2496\% in 1990 and goes to $1,787 \%$ in 2019 . The most representative country for this group is Austria. For this group, the value for 1990 is quite three times more that is was in 2019;

- Cluster 2 with 4 instances (19\%) contains: Greece, Italy, Lithuania, and Slovenia. The value decreases over the years, starting from 7,326\% in 1990 and goes to 4,6633\% in 2019. The most representative country for this group is Greece. For this group, the value for 1990 is less than double than it is was in 2019.

Countries from Cluster 1 are less affected by this problem, and the air quality is better. That is why the amount of money spent for this kind of problem is less than the ones from Cluster 0 and 2. However, Countries from cluster 0 are most affected by the pollution, 
having a low air quality especially around the industrial and very dense populated areas.

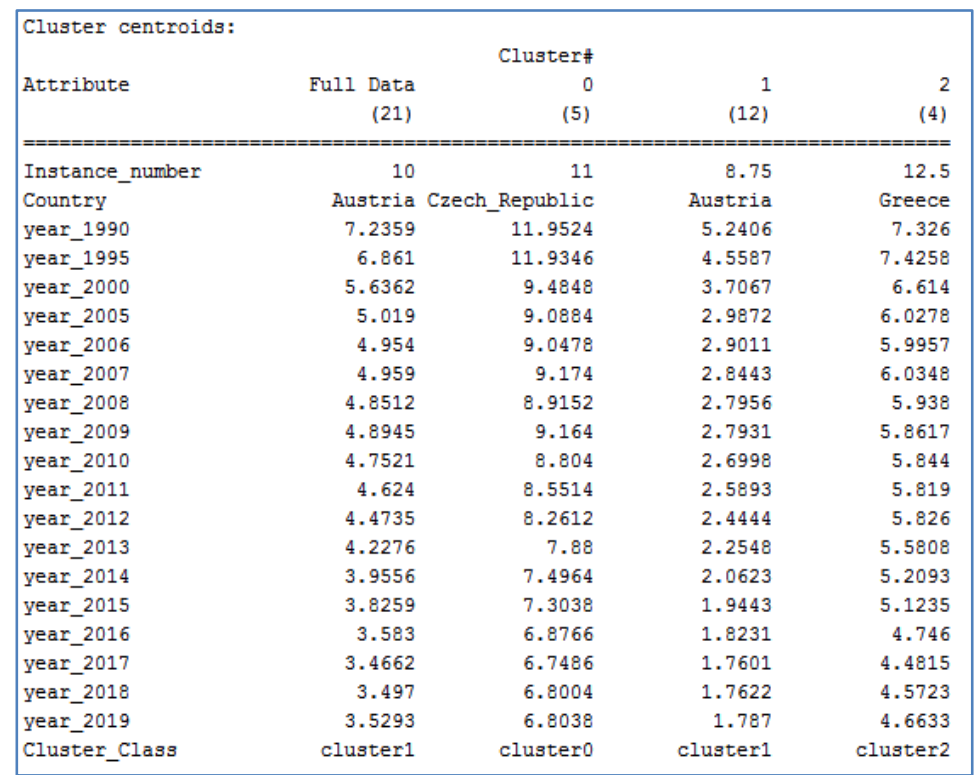

Figure 6: Cluster assignment

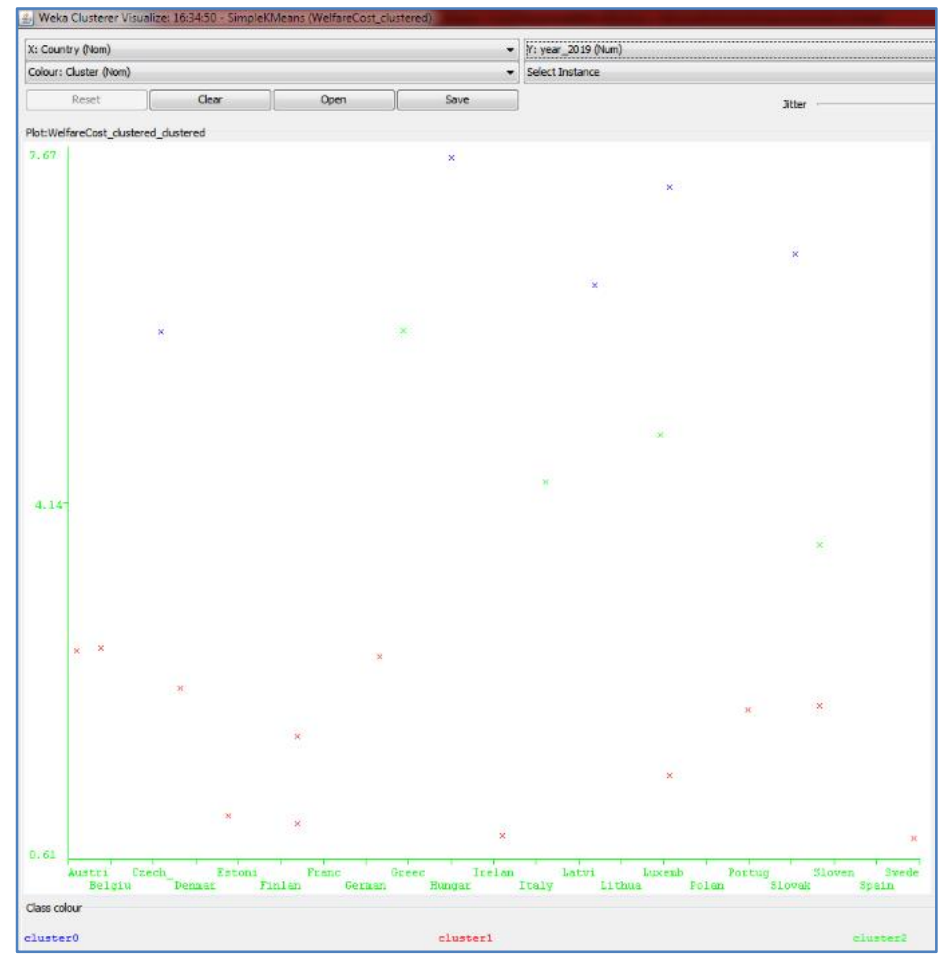

Figure 7. Countries assignment into clusters 


\section{Conclusions}

In order to minimize, combat and anticipate the effects on human health following extreme events and natural disasters that may occur as a result of CC, institutions such as the European Climate and Health Observatory have been created and projects like JRC PESETA were developed and deployed. These institutions have the role of identifying to a large extent, the existing links in CC and human health, as well as all related negative aspects. This paper offers an overview of the most important factors that are affecting the health of the people from the CC point of view and, based on the financial challenge, a data mining analysis is done in order to identify the main groups of countries taking into account percentage of the Gross Domestic Product (GDP) spent on welfare cost of premature deaths due to $\mathrm{CO} 2$ gas emissions, low air quality and pollution.

The consequences of $\mathrm{CC}$ on human health are also felt in terms of medical services and infrastructure that are affected to a large extent. For example, as a result of polluted air and floods, equipment and surfaces dedicated to healing people are affected. Taking into account these aspects, the treatment capacity of the patients is also negatively affected, this being considerably reduced for the affected areas. There were many causes when a single country could not follow these CC factors, the aid received from neighboring countries being of real use.

One possible solution for CC prevention is to create a global market for green and lowcarbon goods and services. This market has now reached over 4,000 billion euros and is growing steadily by over 3\% per year. In terms of mitigating the impact of CC specific factors on human health and beyond, this market can be a medium and long term solution, while also leading to a huge opportunity for the innovative and research sectors, by creating as many green jobs as possible.

\section{References}

Barredo J.I., Mauri A., Caudullo G., (2020) Alpine Tundra Contraction under Future Warming Scenarios in Europe. Atmosphere. 2020; 11(7):698. https://doi.org/10.3390/atmos11070698

Beniston, M., Stoffel, M. (2014), Assessing the impacts of climatic change on mountain water resources, Science of The Total Environment, Volume 493, 2014, Pages 1129-1137, ISSN 0048-9697, https://doi.org/10.1016/j.scitotenv.2013.11.122, https://www.sciencedirect.com/science/article/pii/S0048969713014265]

Bran, F. , Ciobanu, G. , Popescu, M. L.., \& Vasilache, P. C. (2020). Sustainable Local Development in Romania in the Opportunity of Creating Jobs. European Journal of Sustainable Development, 9(3), 287. https://doi.org/10.14207/ejsd.2020.v9n3p287

Burlacu, S., Patarlageanu, S. R., Diaconu, A., \& Ciobanu, G. (2021). E-government in the era of globalization and the health crisis caused by the covid-19 pandemic, between standards and innovation. Les Ulis: EDP Sciences. doi:http://dx.doi.org/10.1051/shsconf/20219208004

CA-EU (2021), site accessed in may 2021, https://climate-adapt.eea.europa.eu/knowledge/adaptationinformation/research-project

CA-OBS (2021). Site accessed in May 2021, https:// climate-adapt.eea.europa.eu/observatory

Carra, C., Burlacu, S., \& Faggianelli, D. (2016). Violence within organizations in the health and medico-social sectors, comparative analysis France-Romania. Administratie si Management Public, (27), 123.

Carra, C., Burlacu, S., \& Faggianelli, D. (2018). Violence within the organizations of health and medico-social sector. A comparative analysis of France and Romania. Economics, Management and Financial Markets, 13(3), 185-202. 
Carra, Cécile; Burlacu, Sorin; Faggianelli, Daniel. Violence in health organizations in romania. The 13th Administration and Public Management International Conference. Policy And Organizational Change In Public Institutions, Oct 2017, București, Romania. 〈hal-01698150〉

Davies, R. (2019). Southern Europe, October to November floods 2019, accessed in May 2021, https://www.efas.eu/en/news/southern-europe-october-november-floods-2019

Dupuy, Jl., Fargeon, H., Martin-StPaul, N. et al. (2020). Climate change impact on future wildfire danger and activity in southern Europe: a review. Annals of Forest Science 77, 35 (2020). https://doi.org/10.1007/s13595-020-00933-5]

EU-RP (2009), European Union, Regional policy, site accessed in May 2021. https://ec.europa.eu/regional policy/sources/docgener/panorama/pdf/mag31/mag31 ro.pdf

Faggianelli, D., Burlacu, S., \& Carra, C. (2018). Victimization of health professionals in Bucharest service relations and social work relationships. Administratie si Management Public, (30), 109-126.

Feyen L., Ciscar J.C., Gosling S., Ibarreta D., Soria A. (editors) (2020). Climate change impacts and adaptation in Europe. JRC PESETA IV final report. EUR 30180EN, Publications Office of the European Union, Luxembourg, ISBN 978-92-76-18123-1, doi:10.2760/171121, JRC119178

Fischer, E., Schär, C. (2010). Consistent geographical patterns of changes in high-impact European heatwaves. Nature Geosci 3, 398-403 (2010). https://doi.org/10.1038/ngeo866

Gallego-Schmid, A., Chen, H-M., Sharmina, M., Mendoza, J.M., (2020). Links between circular economy and climate change mitigation in the built environment, Journal of Cleaner Production, Volume 260, 2020, 121115, ISSN 0959-6526, https://doi.org/10.1016/j.jclepro.2020.121115. https://www.sciencedirect.com/science/article/pii/S0959652620311628

Gentili, R., Bacchetta, G., Fenu, G., Cogoni, D., Abeli, T., Rossi, G., Salvatore, M.C., Baroni, C., \& Citterio, S. (2015). From cold to warm-stage refugia for boreo-alpine plants in southern European and Mediterranean mountains: the last chance to survive or an opportunity for speciation?, Biodiversity, 16:4, 247-261, DOI: $10.1080 / 14888386.2015 .1116407$

Khalil, C.A., Conforti, P., Ergin, I., Gennari, P. (2017) Defining Small-scale Food Producers to Monitor Target 2.3. Of the 2030 Agenda for Sustainable Development, Food Agric. Org. United Nations (2017), p. 17, http://www.fao.org/3/i6858e/i6858e.pdf

Koutroulis, A.G., Papadimitriou, L.V. Grillakis, M.G., Tsanis, I.K. Warren, R., Betts, R.A., (2019). Global water availability under high-end climate change: A vulnerability based assessment, Global and Planetary Change, Volume 175, 2019, Pages 52-63, ISSN 0921-8181, https://doi.org/10.1016/j.gloplacha.2019.01.013.

https://www.sciencedirect.com/science/article/pii/S0921818118305393]

Lhotka, O., Kyselý, J. \& Farda, (2018). A. Climate change scenarios of heat waves in Central Europe and their uncertainties. Theor Appl Climatol 131, 1043-1054 (2018). https://doi.org/10.1007/s00704-0162031-3]

Menne B. (2015). Climate change and human health, https://www.eea.europa.eu/signals/signals2015/interviews/climate-change-and-human-health, accessed may, 2021

Newbery, D., (2016). Towards a green energy economy? The EU Energy Union's transition to a low-carbon zero subsidy electricity system - Lessons from the UK's Electricity Market Reform, Applied Energy, Volume 179, 2016, Pages 1321-1330, ISSN 0306-2619, https://doi.org/10.1016/j.apenergy.2016.01.046

Özerol, G., Dolman, N., Bormann, H., Bressers, H., Lulofs, K., Böge, M., (2020). Urban water management and climate change adaptation: A self-assessment study by seven midsize cities in the North Sea Region, Sustainable Cities and Society, Volume 55,2020,102066,ISSN 22106707,https://doi.org/10.1016/j.scs.2020.102066.

https://www.sciencedirect.com/science/article/pii/S2210670720300536)]

Peptenatu, D., Sirodoev, I. \& Pravalie, R. (2013). Quantification of the aridity process in South-Western Romania. J Environ Health Sci Engineer 11, 5 (2013). https://doi.org/10.1186/2052-336X-11-5

PESETA (2021) - Project PESETA IV, https://ec.europa.eu/jrc/en/peseta-iv

Pricop, L. C., Burlacu, S., \& Demeter, M. L. (2016). Managing violence in health sector through bi solutions. In Proceedings of the International Management Conference (Vol. 10, No. 1, pp. 512-519). Faculty of Management, Academy of Economic Studies, Bucharest, Romania. 
Rădulescu, C. V., Bran, F., Burlacu, S., Dobrea, C. R., \& Diaconu, S. (2020, December). Challenges Regarding Food Resources in the Context of Globalization and Population Growth. In Proceedings of the International Conference on Economics and Social Sciences (pp. 1041-1052). Sciendo.

Ricciardi, V., Ramankutty, N., Mehrabi, Z., Jarvis, L., Chookolingo, B., (2018). How much of the world's food do smallholders produce?, Glob. Food Security, 17 (2018), pp. 64-72, 10.1016/i.gfs.2018.05.002

Ruffault, J., Curt, T., Moron, V. et al. (2020), Increased likelihood of heat-induced large wildfires in the Mediterranean Basin. Sci Rep 10, 13790 (2020). https://doi.org/10.1038/s41598-020-70069-z

Sarbu, R., Alpopi, C., Burlacu, S., \& Diaconu, S. (2021). Sustainable urban development in the context of globalization and the health crisis caused by the covid-19 pandemic. Les Ulis: EDP Sciences. doi:http://dx.doi.org/10.1051/shsconf/20219201043

STAT-OECD (2021), accessed in May 2021, https://stats.oecd.org/

Talukder, B., van Loon, G., Hipel, K., Chiotha, S., Orbinski, J. (2021). Health impacts of climate change on smallholder farmers, One Health, Volume 13, 2021, 100258, ISSN 2352-7714, https://doi.org/10.1016/i.onehlt.2021.100258

WHO-CL (2021), World Health Organization, site accessed in May 2021, https://www.who.int/globalchange/climate/en/chapter3.pdf 